\title{
EDITORIAL
}

Rudolf Heuer • Michael Krommer • Alexander Belyaev

\section{Dedicated to Professor Hans Irschik on the occasion of his 60th birthday}

Published online: 20 June 2012

C) Springer-Verlag 2012

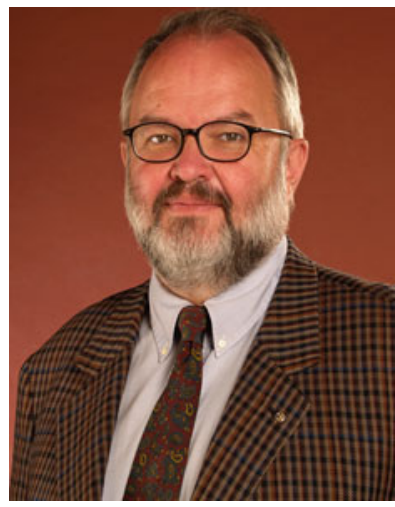

Hans Irschik, distinguished Professor of Technical Mechanics, celebrated his 60th birthday in August 2011. Furthermore, 2011 marks the 20th anniversary of his activities as Professor of Technical Mechanics and as Director of the Institute of Technical Mechanics at the Johannes Kepler University of Linz.

This special issue of ACTA MECHANICA is dedicated to Professor Hans Irschik, and we, the three undersigned colleagues of Professor Irschik, feel honored and privileged to act as guest editors of this issue.

Hans Irschik studied Civil Engineering at the Vienna University of Technology and received his diploma in 1977. As an assistant to Professor Franz Ziegler, he joined the "Vienna School of Mechanics". In 1981, he obtained his Doctorate in Technical Sciences with honor. After his Habilitation in Mechanics in 1986, he was appointed as a Full Professor and Head of the Institute of Technical Mechanics at the Johannes Kepler University of Linz (JKU) in 1991. At that time, JKU implemented a brand new curriculum "Mechatronics", which turned out to be the first full curriculum for this subject in Europe. Along with a few other professors of JKU, he developed a principally new concept for teaching "Mechatronics" in Austrian universities and for implementing "Mechatronics" into Austrian technology.

R. Heuer

Vienna, Austria

M. Krommer $(\bowtie)$

Linz, Austria

E-mail: krommer@mechatronik.uni-linz.ac.at

A. Belyaev

St. Petersburg, Russia 
Professor Irschik has significantly contributed to governing JKU; he successfully acted as Vice-Rector for research from 1995 until 2001, and from 2009 to present, he is the acting Head of the University Senate. Professor Irschik has played an important role in implementing mechatronic ideas into Austrian technology, and he has put enormous energy in establishing both the Linz Center of Mechatronics (LCM) and the Austrian Center of Competence in Mechatronics (ACCM).

In 2007, Professor Irschik was elected as a corresponding member of the Austrian Academy of Sciences and a full member in 2011. In 2009, he was awarded a Honorate Doctorate (doctor honoris causa) of the St. Petersburg State Polytechnic University.

Hans Irschik has been working at the very frontier of mechanics in a highly remarkable number of fields, such as control of structures, mechatronic systems, modeling of dynamical systems, theory of plates, piezoelasticity, wave propagation in random media, deterministic and random vibrations in elastic and inelastic structures, thermal stresses, fluid-structure interaction, dynamic plasticity, nonlinear dynamics of structures, computational and experimental methods of mechanics, earthquake engineering, and advanced continuum mechanics, to mention only some of his many topics of interest. In all of these areas, Hans Irschik has obtained outstanding scientific results of lasting importance, reported in about 350 scientific publications as contributions to books, publications in international journals, and refereed proceedings. Many times he was invited as visiting professor and lecturer in various countries within Europe, the U.S.A., and Japan.

We, the undersigned, among many others, have had the privilege of being students, doctoral students, assistants, and research colleagues of Professor Irschik, who always has taught Mechanics with enthusiasm and - though on a high academic level—clearly and understandably. Students in civil and mechanical engineering, mechatronics as well as in natural sciences have attended his courses at TU Vienna and JKU Linz with the greatest benefit.

Professor Hans Irschik has been working intensively, passionately, and successfully on the development of the international mechanics community. He is a member of a number of international scientific societies, namely ASME, AIAA, SPIE, GAMM, EUROMECH, ISIMM and OIAV. Presently, Hans Irschik is the President of the European Association for the Control of Structures (EACS). He is a member of editorial boards of important international scientific journals and Editor as well as Managing Editor of ACTA MECHANICA.

We sincerely thank all the authors, who have contributed to this issue, for which the manuscripts, according to the ACTA MECHANICA rules, were reviewed before acceptance. Certainly, due to the limited space available in one issue, just a small number of scientists belonging to the large circle of friends and colleagues of Hans Irschik could be invited to contribute. We also would like to thank the many authors who have dedicated publications to Professor Hans Irschik on the occasion of his 60th birthday in other journals. 